\title{
PRIORITIES AND THE DISCHARGE OF CAVEATS: WHITE RESOURCE MANAGEMENT LTD. v. DURISH
}

\section{W.H. HURLBURT*}

The recent Alberta Court of Queen's Bench decision in White Resource Management raises $a$ complex issue: under what circumstances, if any, should caveated interests lose their priority? Mr. Hurlburt analyzes White Resource Management, along with other cases on the same issue, and makes recommendations on the policy choices that these cases bring out.
La décision récente de la Cour du banc de la Reine de l'Alberta dans la cause White Resource Management soulève une question complexe: dans quelles circonstances les droits protégés par une mise en demeure doivent-ils perdre leur rang privilégié? M. Hurlburt analyse la cause en question et dautres cas similaires, et propose certaines recommandations relatives aux décisions administratives auxquelles ils pourraient donner lieu.

\section{TABLE OF CONTENTS}

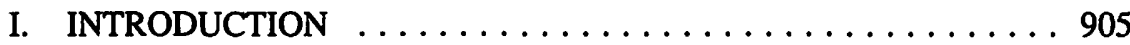

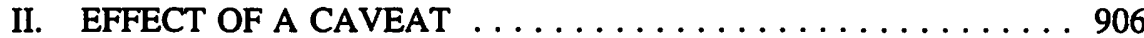

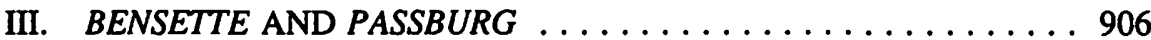

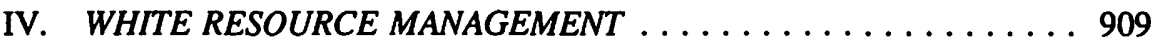

V. ALBERTA (MIN. OF FORESTRY,

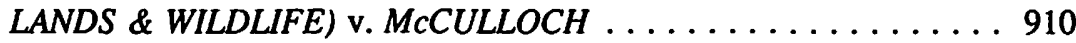

VI. THE LAW FOLLOWING BENSETTE, PASSBURG,

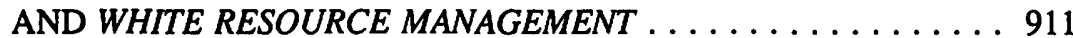

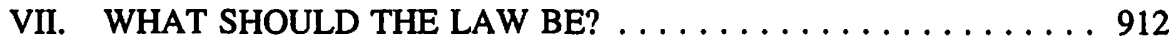

VIII. CONCLUSION ...................... 914

\section{INTRODUCTION}

This note is provoked by the decision of Mr. Justice Mason in White Resource Management Ltd. v. Durish. ${ }^{1}$ It is about that case ${ }^{2}$ and the earlier cases of Bensette v. Reece ${ }^{3}$ and Re Passburg Petroleums Ltd. and Landstrom Developments Ltd. ${ }^{4}$ It addresses two questions that are raised by the three cases and that are important to conveyancers.

Suppose that $O$, the owner of a parcel of land, grants an interest to $A$, who registers a caveat to protect the interest. Suppose that $O$ grants a conflicting interest to $B$, who also registers a caveat. Suppose further that A's caveat is discharged without A's authority but that A's interest is not extinguished.

- Director emeritus, Alberta Law Reform Institute, and counsel to Reynolds, Mirth, Richards and Farmer, Edmonton.

1. (1991), 77 Alta L.R. (2d) 131 (Q.B.) (hereinafter White Resource Management).

2. It also refers to Alberta (Min. of Forestry, Lands \& Wildlife) v. McCulloch, [1991] 3 W.W.R. 662 (Alta Q.B.) (hereinafter $\mathrm{McC}$ ulloch).

3. [1973] 2 W.W.R. 497 (Sask. C.A.) (hereinafter Bensette).

4. (1984), 8 D.L.R. (4th) 363 (Alta C.A.) (hereinafter Passburg). 
The first question which arises from these facts is: does A's interest continue to have priority over B's interest? All three cases say yes. This may mean that registering a discharge of a prior caveat during a conveyancing transaction does not assure a purchaser or mortgagee of obtaining a clear title or first charge.

The second question is: if, after the discharge of A's caveat, B assigns his or her interest to $B 1$, who registers a caveat, does A's interest continue to have priority over the interest which was owned by B and is now owned by B1? White Resource Management says yes. If the judgment is good law, it means that persons who take an assignment of a caveated interest may find themselves subject to an interest which was not caveated or registered when they took the assignment.

Are these cases good law? If so, is the law satisfactory? In order to answer these questions it is necessary to consider the nature of a caveat and to analyze the reasons for judgment given in the three cases.

\section{EFFECT OF A CAVEAT}

"Registration by way of caveat," says section 145 of the Land Titles Act, "has the same effect as to priority as the registration of any instrument under this Act." ${ }^{\text {" }}$ The registration of a caveat therefore confers priority only. It does not, as does the registration of an interest, confer legal ownership of the caveated interest. The registration of a caveat is effective only if the general law says that the caveated interest exists and is owned by the caveator. Similarly, the termination of the registration of a caveat does not of itself terminate the caveated interest: it merely allows the interest to be subordinated to subsequent registered and caveated interests.

\section{BENSETTE AND PASSBURG}

In Bensette, B bought a parcel of land subject to A's caveat. B then caused the Registrar to serve a notice on $A$ that the caveat would lapse unless a judge's order continuing it was filed. ${ }^{6}$ The Registrar sent the notice to the 30-year-old address for service shown on the caveat, which was the office of a law firm. The law firm's successors received the notice but were not able to send it to the caveators, because one caveator was dead and the envelope addressed to the other was returned. No judge's order having been obtained, the caveat lapsed and was removed from the certificate of title. The caveators later sued for a declaration that they were entitled to the caveated interest in priority to $B$, and for consequential relief. They were unsuccessful at trial but succeeded in the Saskatchewan Court of Appeal.

The trial judge had held that B was protected by the Saskatchewan counterpart of section 195 of the Alberta Land Titles Act, under which a person dealing with a registered

5. Emphasis added.

6. This procedure is the counterpart of the procedure prescribed by section 137 of the Land Titles Act and has the same effects. Hall J.A. in Bensette at 513 suggested that the Alberta section is more favourable to $B$, but the reason advanced is not persuasive. 
owner is not obliged to inquire into the circumstances and is not affected by notice of an unregistered interest. Woods J.A., one of the two members of the majority, ${ }^{7}$ contented himself with holding that the section did not protect B. It did not apply when B bought the parcel, because A's interest at that time showed on the register. It did not apply when the caveat was removed, because B did not then deal in any way with a registered owner. ${ }^{8}$ Woods J.A. did not refer to any of the other provisions of the Land Titles Act.

Hall J.A., the other member of the majority, agreed with Woods J.A. However, he went on to hold ${ }^{9}$ that a caveated claim attaches to the estate acquired by a transferee, and that the subsequent lapse of the caveat does not extinguish the caveated rights and does not have the retroactive effect of changing the relative priorities of the interests. Accordingly, the lapse of the caveat does not improve or enhance the transferee's estate. This latter proposition is consistent with the legal theory which has been built up around caveats in Western Canada and is therefore a firmer foundation for the judgment than that given by Woods J.A., but, in Bensette, only Hall J.A. enunciated it.

In Passburg, $\mathrm{O}$ granted a surface lease to $\mathrm{A}$, which registered a caveat. B bought the parcel and became registered as owner subject to A's caveat. A assigned the lease to Al. A later discharged its caveat. Still later, A1 caveated. B sued for a declaration that the surface lease was not enforceable against it. Although B was successful at trial, Al obtained from the Alberta Court of Appeal declarations that B's title was subject to Al's claim, and that Al's caveat was valid and dated back to O's title. The principle is the same as the Bensette principle, as Al was entitled to the benefit of A's caveat and the discharge of the caveat was not authorized by $\mathrm{A} 1$.

The essence of the decision in Passburg is that privity of estate arose when B took title subject to A's caveat and did not end because of the mere discharge of A's caveat. That privity of estate made B and A1 "immediate parties" whom (like volunteers) the Land Titles Act is not designed to protect. Section 64 of the Land Titles Act must be read in light of the overall intent of the Act, and "clearly means that the registered owner is entitled to rely upon his certificate of title as he obtained it."10 The judgments of both Woods J.A. and Hall J.A. in Bensette are referred to with apparent approval.

There are two circumstances which might throw some doubt on Bensette and Passburg. The first is that the Supreme Court of Canada had held in Union Bank of Canada v. Boulter Waugh Limited ${ }^{11}$ that, where a registered mortgagee caused a caveat protecting a prior equitable mortgage to lapse, the priority of the prior equitable mortgage was lost. That is, B, a registered mortgagee, obtained priority over the interest of A, a prior equitable caveated mortgagee, by causing A's caveat to be removed from the register without A's authority.

7. Brownridge J.A. dissented on the grounds that the case was governed by Boulter Waugh, infra, note 11.

8. At 502.

9. At 513.

10. Emphasis added.

II. (1919), 58 S.C.R. 385 (hereinafter Boulter Waugh). 
The facts of Boulter Waugh appear to be on all fours with Bensette. They appear to be close enough to attract the same principles as the facts in Passburg. In Bensette, however, both members of the majority distinguished Boulter Waugh. Woods J.A. distinguished it on the grounds that it was a contest between two encumbrances. This is not a satisfactory distinction: it is difficult to see why a registered owner of a fee simple estate should not be able to improve his or her position by bringing about the lapse of a prior caveat if a registered mortgagee can do so. Hall J.A. distinguished it $^{12}$ on a different and possibly more satisfactory ground, namely that it simply did not deal with the caveat point (upon which, he said, the appellants in Boulter Waugh chose not to rely), but turned instead on the effect on a registered second mortgagee of notice of a prior equitable interest. Distinguishing Boulter Waugh on this ground necessarily involves some risk that the Supreme Court, on a future occasion, will think it a rather cavalier way of disposing of one of its decisions. Perhaps, however, the fact that two courts of appeal have managed either to distinguish Boulter Waugh (Bensette) or ignore it (Passburg) means that it can safely be forgotten.

The second circumstance which might throw some doubt on Passburg, at least, has to do with section 135 of the Land Titles Act. Before the 1982 amendment, the section read in part as follows: "so long as a caveat remains in force the Registrar shall not register an instrument purporting to affect the land, mortgage or encumbrance in respect of which the caveat is lodged, unless the instrument is expressed to be subject to the claim of the caveator." Counsel for the respondent in Passburg argued that the withdrawal of the caveat withdrew the claim and referred to section 64 of the Land Titles Act, which provides that the registered owner holds the land subject to the interests notified on the register and free of everything else.

Moir J.A. rejected this argument. He held that section 135 merely told the Registrar that a caveat, so long as it remained in force, protected the caveator for the interest claimed in the caveat from dealings by third parties. If a caveat was withdrawn, a third party might rely on the register and deal with the registered owner, but a registered owner does not, under such circumstances, rely on the register. Stevenson J.A., who gave concurring reasons, said: "The section does not purport to establish or affect rights inter se. It is directed to the registrar and, inferentially, to third parties. ${ }^{13}$ These interpretations were clearly in accordance with the literal wording of the section as it then stood.

However, in 1982, section 135 was re-enacted in different terms. ${ }^{14}$ It now provides that "so long as a caveat remains in force an instrument registered subsequent to the caveat and purporting to affect the land, mortgage or encumbrance in respect of which the caveat is lodged is subject to the claim of the caveator." This is not a direction to the Registrar. It is a statement of law about priorities. It lays down a priority rule which applies while a caveat is registered. The 1982 section therefore does away with the 
reason given by the Court of Appeal for refusing to apply section 135 in Passburg and substitutes a reverse legal situation.

A reader who was accustomed to apply legal principles of interpretation and who came upon the present section 135 afresh might well think that a legislative statement that a legal rule is to apply so long as a caveat remains in force excludes the application of that rule when the caveat is no longer in force: expressio unius est exclusio alterius. If the circumstances of Passburg arise again, there may be counsel sufficiently bold to litigate the meaning of the substituted section and to argue that it is only while a caveat remains in force that a subsequent interest is subject to the caveated interest.

It is not clear why the 1982 section was not argued in the Passburg case. ${ }^{15}$ According to the statute book, S.A. 1982, c. 23 came into force on October 1, 1982. A's caveat had been discharged by that time, and it was later that Al registered its caveat and commenced its action, so it seems that there was a possible, though by no means unchallengeable, argument that the new section applied. However, the court referred exclusively to the superseded version of section 135 .

\section{WHITE RESOURCE MANAGEMENT}

As indicated above, White Resource Management has carried the logic of Bensette and Passburg one step further. The case is almost unbearably complicated ${ }^{16}$ and it may be that the whole matrix of facts had a bearing on the result, but the facts upon which Mason $J$. founded his reasons for judgment are essentially that B1 took and caveated an assignment of B's interest at a time when A's caveat had been discharged. The question was whether the Bensette and Passburg principle continued A's priority (and that of A's lessee) over a third party who acquired B's caveated interest when A's interest did not appear in the register.

Mason J. distinguished the Boulter Waugh case on the grounds that, in White Resource Management, B1 did not deal with a registered owner and was therefore not protected by section 195 of the Land Titles Act. This is clearly correct and within Bensette: a purchaser from a caveated owner does not obtain the ownership protection that is obtained by a purchaser from a registered owner.

Mason J. went on to apply Bensette and Passburg. He held that the discharge of A's caveat did not destroy the privity of estate between A and B. He then went past Bensette and Passburg to hold that B1 took B's interest subject to interests which were prior to it when it was in B's hands. There are two reasons for thinking that the ground is less firm here.

15. The editors of the Westem Weekly Reports inserted in square brackets a reference to what they considered to be the "re-enactment" of the section, but it is quite clear that it was only the old section which the Court of Appeal contemplated, as it was quoted by Moir J.A. and the remarks of the court were clearly directed towards it. 
First, the change in section 135 of the Land Titles Act undermined the reasons given by the Court of Appeal in Passburg for holding that section 135 does not imply that the priority of a caveated interest terminates upon the discharge of the caveat. Second, and more important, section 145 provides that registration by way of caveat has the same effect as to priority as the registration of an instrument. But the registration of an instrument confers priority on the interest conferred by the registration over all interests that are not then caveated or registered, except for overriding interests, and B's caveat was registered when A's interest was not caveated or registered.

The facts in White Resource Management brought two principles into conflict. One is that, once the caveating of an interest has established its priorities in relation to other registered and caveated interests, those priorities should continue despite the removal of the caveat. The second is that registration or caveating establishes priority over all interests other than overriding interests which are not reflected in the register. Mason J. accepted and applied the first.

It is understood that White Resource Management is under appeal. The law must be regarded as uncertain until it is settled by an appellate judgment.

\section{ALBERTA (MIN. OF FORESTRY, LANDS \& WILDLIFE) v. MCCULLOCH ${ }^{17}$}

In $M c C$ ulloch, $\mathrm{O}$ granted an interest to $\mathrm{A},{ }^{18}$ which $\mathrm{A}$ caveated. $\mathrm{O}$ then sold the land to B. A's caveat was discharged by error of the Land Titles Office. B then transferred the land to B1, which was a corporation owned by B and his wife. A sued for, and obtained, declarations that B and B1 were guilty of fraud and that B1's interests were subject to A's interests. The doctrine of White Resource Management, if valid, would have been another ground for a decision in A's favour, but the point was not dealt with in the judgment and presumably was not argued.

It is implicit in McCulloch that B was bound by A's interest despite the discharge of A's caveat. The decision is therefore consistent with Bensette and Passburg, but, as the continued priority of A's interest over B's interest was assumed rather than decided, the decision does not add much to a discussion of that issue. The case is mentioned here only because of its currency.

17. Supra, note 2 .

18. There was actually a sale by $A$ (the Crown) to $O$ under the terms of which $O$ agreed to use the land for a certain purpose and granted the Crown an option to repurchase the land for a stated price if $A$ ceased to use the land for that purpose. The effect, however, is that the purchaser became the owner and granted the interest to the vendor. It seems to have been assumed that there was a valid interest in land. 


\section{THE LAW FOLLOWING BENSETTE, PASSBURG, AND WHITE RESOURCE MANAGEMENT}

Bensette and Passburg may be unobjectionable on the peculiar facts of those cases. Perhaps an owner should not be able to promote the priority of his interest by sending a notice to an obsolete address for service. Perhaps an assignee should not be prejudiced merely because her assignor discharges a caveat. However, if the two cases lay down a principle which will apply in all cases in which A's caveat is removed from the register, they may cause the difficulties for conveyancers that are suggested at the beginning of this note.

It is not uncommon for $O$ to sell or mortgage to $B$ land which is subject to a caveat by $A$, with the intention that as part of the completion of the transaction $A$ 's interest will be paid out and A's caveat discharged. Sometimes it will even be necessary for B to register the title or mortgage while A's caveat remains on the register; conveyancing or refinancing considerations may require it.

If Bensette and Passburg apply, the removal of A's caveat from the register during the conveyancing process will not necessarily protect $B$ 's priority. The discharge may be forged or otherwise unauthorized. It may have been delivered in error. The unauthorized removal of A's caveat will not deprive A's interest of its priority over B's interest, so that B will find himself or herself with an unexpected prior interest. The priority of B's interest depends upon the validity of the discharge. Upon an extreme interpretation, B could remain subject to A's interest even if A gave a discharge of caveat but did not surrender the interest, though it is likely that a court would find a means, probably through estoppel, of avoiding that result.

If Bensette and Passburg cause a problem by saying that a purchaser cannot rely on an invalid discharge of caveat, the answer appears simple: let conveyancers investigate to determine whether discharges of caveats delivered to them in the course of conveyancing transactions are valid and binding on those who appear to have signed them. However, this simple answer is not practical. Conveyancers do not have the resources to investigate the authenticity of documents. If they were to do so, the resulting cost and delay would inhibit land transactions. The purpose of a land registration system is to allow users of the system to rely on the register, and preserving the priority of interests which are not registered or caveated detracts from the achievement of that purpose. The Bensette and Passburg principle is, in my opinion, contrary to good land registration policy if it applies to a case in which B in good faith pays out his or her money on the strength of the discharge of a caveat.

White Resource Management, if it is good law, gives rise to a different problem. It is that purchasers who rely on the register when taking an assignment of a caveated interest may find themselves subject to a prior interest which does not appear in the register. This situation is also, in my opinion, contrary to good land registration policy.

The law at this point may be summarized as follows: 
(1) Bensette and Passburg are authority for the proposition that an interest which is registered or caveated subject to a prior caveated interest remains subject to the prior caveated interest even if the prior caveat is removed from the register. ${ }^{19}$ The Boulter Waugh decision and the revision of section 135 of the Land Titles Act leave some small room for doubt about this proposition, and it does not necessarily follow from Bensette and Passburg that the proposition will be extended to cases in which B changes his or her position in reliance upon the removal of the caveat from the register or to cases in which A actually signs the discharge of caveat but retains the interest. However, there is a significant risk, even in such a case, that A's interest will continue to have priority.

(2) White Resource Management is authority for the proposition that the interest of an assignee who acquires a caveated interest is subject to an interest which had been caveated when the assignor acquired the caveated interest, despite the removal of the prior caveat from the register before the assignment took place. This proposition remains doubtful pending an appellate decision.

There is an anomaly here. It seems likely, since Frazer v. Walker ${ }^{20}$ and Hermanson v. Martin, ${ }^{21}$ that a registered interest which is discharged on the strength of an unauthorized instrument will lose its priority over the interest of a bona fide purchaser for value who obtains the benefit of the discharge. But registration is intended to give greater protection than is caveating, and it is inconsistent for the law to continue to protect a caveated interest after the discharge of the caveat in circumstances where it does not protect a registered interest after the discharge of the registration.

\section{WHAT SHOULD THE LAW BE?}

The law as outlined in this note is not altogether satisfactory. Most users of the system are likely to prefer to be able to clear title, and not merely to clear the register, by registering a discharge of caveat. Most users are likely to prefer to be able to acquire a caveated interest free from prior interests not shown in the register. A derogation from the right to rely on the register derogates from facility of transfer and therefore from the business efficiency which title registration is intended to promote.

In 1990, a Joint Land Titles Committee recommended for adoption by Canadian provinces and territories a Model Land Recording and Registration Act. ${ }^{22}$ This model act adopts the principle of Bensette and Passburg. It rejects the principle of White Resource Management.

The Alberta Law Reform Institute has issued a report for discussion which tentatively recommends the adoption of a land recording and registration statute along the general

19. White Resource Management is also authority for this proposition.

20. [1967] 1 A.C. 569 (P.C.).

21. [1987] 1 W.W.R. 439 (Sask. C.A.).

22. The model act is contained in the joint committee's report Renovating the Foundations: Proposals for a Model Land Recording and Registration Act for the Provinces and Territories of Canada, which is dated July 1990. 
lines of the joint committee's model act. ${ }^{23}$ However, most of those consulted by the institute thought that the application of Bensette and Passburg to a case in which a purchaser gives value on the strength of an unauthorized discharge of caveat, even though it may be the present law, is unsatisfactory. The institute has the question under consideration and will deal with it in its final report on the subject.

The alternative policy choices which might reasonably be made where A's prior caveat has been removed from the register without A's authority at a time when B's interest is registered or caveated (the Bensette and Passburg situation) appear to be as follows:

(a) A's interest always retains its priority over B's interest. ${ }^{24}$

(b) A's interest always retains its priority unless B relies on the removal of the caveat and gives value for the removal.

(c) A's interest retains its priority over B's interest only in two cases: first, where A's caveat is removed on the strength of the service of a lapsing notice by registered mail addressed to the address given for $A$ in the Land Titles Office records and A did not receive the notice; and, second, where A's caveat is removed by the Registrar's error.

(d) A's interest always loses its priority.

Choice (a) derogates from the facility of transfer which land registration is established to promote. Choice (d), on the other hand, may confer a windfall advantage on B and go further than the promotion of facility of transfer requires, since it would reverse Bensette and Passburg on their facts, which is undesirable. Choice (c) comes closer to a proper balancing of interests, but it focuses on matters which relate to $A$, while land registration is more concerned with matters relating to purchasers, that is, to B.

My preference is choice (b). It would protect the persons whom land registration is intended to protect, that is, persons who acquire interests in land without fraud. However, it may be that, even if this option is adopted, it should benefit B only if B registers his or her interest; giving an immediate party the benefit of an invalid immediate transaction would be an extraordinary measure.

The policy choices which might reasonably be made where A's prior caveat has been removed from the register at a time when B1 acquires an assignment of B's caveated interest appear to be as follows:

(a) A's interest always retains its priority over B's interest when that interest has come into B1's hands.

23. Alberta Law Reform Institute, Towards a New Alberta Land Titles Act, Report for Discussion No. 8, August 1990.

24. It is assumed in each of these choices that B has not been guilty of fraud. 
(b) B1's interest gains priority over A's interest if B1 acquires without fraud an assignment of B's interest, and if Bl caveats or registers the interest at a time when A's interest was not registered and caveated.

My preference is choice (b). It appears to me to promote facility of transfer in a way that is contemplated by and consistent with land registration principles.

\section{CONCLUSION}

The conveyancing climate of common law Canada has severely eroded the original Torrens theory that the register is everything and that an unregistered interest is nothing. Much of the erosion - the recognition between immediate parties of unregistered interests, and the protection against the world of the priorities of caveated interests - has been beneficial. However, the extent to which the priorities of a caveated interest should be protected after the discharge of the caveat needs further attention.

\section{APPENDIX}

\section{Facts of White Resource Management}

In May, 1968, Carlson, the beneficial owner (who later became the registered owner), agreed to sell land including minerals to Vold, who registered a caveat.

In November, 1971, Carlson's estate leased the minerals to Pawnee, which assigned to Brascan, which assigned to Haida. All three caveated. Brascan discharged its caveat after it assigned to Haida.

In October, 1976, the then owners and beneficial owners of the minerals (being Carlson's living heirs and the estates of his deceased heirs) granted options to lease to Normac, which assigned to White Resource Management, which registered caveats.

In December, 1977, White Resource Management (which was then claiming only as assignee of the Normac options) served on Pawnee, Haida and Vold notices to take proceedings on their respective caveats. Pawnee and Vold did nothing and their caveats lapsed. The registrations were cancelled in February and March 1978 respectively. In January 1978, Haida commenced an action to defend the Pawnee lease and registered a lis pendens.

In May 1978, Vold leased the minerals to White Resource Management, which registered a caveat. White Resource Management then had two interests, one under the assignment from Normac and one under the lease from Vold, and the certificate of title showed the competing claims of Haida and White.

In May 1979, Durish obtained an assignment from Haida of the Pawnee lease and registered a caveat. (Later, he agreed to buy the minerals from Vold and took an assignment of Vold's interest as lessor under Vold's lease to White Resource Management, but nothing seems to turn on this.) 
The judgment describes at length dealings between White Resource Management, on the one hand, and Durish and his company Dobell, on the other. Nothing appears to depend on these dealings.

The decisive factor was the judge's view of the relative priorities of the White Resource Management lease from Vold and the Pawnee lease under which Durish claimed. The sequence of events which determined the relative priorities was as follows: (a) the agreement for sale by Carlson to Vold, caveated by Vold; (b) the Carlson estate lease to Pawnee, its assignment to Haida, Haida's caveat, and the assignment to Durish; (c) the lapsing of Vold's caveat; (d) the lease from Vold to White Resource Management at a time when Vold's interest was not caveated and the Pawnee lease through which Durish claimed was caveated; and (e) White Resource Management's caveat protecting the lease from Vold. On the register, Haida's caveat was first, but Vold's caveat was on the register when Pawnee acquired the lease from the Carlson estate and when Haida obtained and caveated its assignment of that lease.

Using the example at the beginning of this note, the interest of $A$ (Vold) was caveated at the time of the lease to B (Pawnee) and the assignment to B's successor (Haida). The discharge of A's caveat left A's interest prior to B's interest, and that priority continued when B1 (Durish) acquired B's interest at a time when A's interest did not appear on the register. 